\title{
Evaluating pond sand filter as sustainable drinking water supplier in the Southwest coastal region of Bangladesh
}

\author{
M. A. Y. A. Harun • G. M. M. Kabir
}

Received: 15 October 2011/Accepted: 26 November 2012/Published online: 11 December 2012

(C) The Author(s) 2012. This article is published with open access at Springerlink.com

\begin{abstract}
This study investigates existing water supply scenario, and evaluates the performance of pond sand filter (PSF) in meeting drinking water demand of Dacope Upazila in southwest coastal Bangladesh. Questionnaire survey to the villagers reveals that PSF is the major drinking water sources $(38 \%)$ of the study area followed by tubewells $(30.4 \%)$, rainwater harvesting (RWH) systems $(12.6 \%)$, ponds $(10.3 \%)$ and others $(8.7 \%)$. The spot test and laboratory analysis show that odour, colour, $\mathrm{pH}$, dissolved oxygen, hardness, calcium, magnesium, nitrate, sulphate and phosphate of the PSFs water meet Bangladesh standard. The efficiency of PSF in reducing total dissolved solids (TDS) (15\%) and potassium (8.2\%) is not enough to meet the standard of $20 \%$ PSFs for TDS and one-third PSFs for potassium. The study proves that PSF is unable to remove coliform bacteria by $100 \%$ from highly contaminated water. Hence, disinfection should be adopted before distribution to ensure safe drinking water. Majority of the PSF's users $(80 \%)$ are either partially satisfied or dissatisfied with the existing system. The beneficiary's willingness to pay for drinking water technologies seems that the combination of PSF and RWH could ensure sustainable drinking water in coastal region of Bangladesh.
\end{abstract}

Keywords Sustainable - Coastal region - PSF - RWH . Dacope $\cdot$ Bangladesh

M. A. Y. A. Harun $(\bowtie) \cdot$ G. M. M. Kabir

Environmental Science Discipline,

Khulna University, Khulna, Bangladesh

e-mail: harunkb@yahoo.com

\section{Introduction}

Providing adequate amounts of drinking water of an acceptable quality is a basic necessity, and ensuring sustainable, long-term supply of such drinking water is of national and international concern. The majority of the populations in developing countries still lack safe drinking water and more than $50 \%$ of the populations have no access to potable water (UNDP 1992). Bangladesh, a densely populated developing country with very low literacy rate and sanitary awareness had achieved a great success ensuring safe drinking water to rural people through providing tubewells for extracting ground water by the year 1990 (Ahmed and Rahman 2000). Severe arsenic contamination of groundwater in Bangladesh has disrupted the idea of using shallow tubewells for safe drinking water throughout the country (Karim and Safiuddin 2003). WHO (2004) reported that in southwest Bangladesh (Khulna, Satkhira and Bagerhat district) the ground water is unsuitable for human consumption due to high salinity rather than due to arsenic contamination that may be of importance in the northern parts of Bangladesh. The availability of saline-free pockets in coastal areas is lower than the availability of arsenic-free pockets in the arsenicaffected rural villages, where in places neither ground nor surface water is saline-free (Rahman et al. 1997). Although deep tubewells of coastal areas provide a relatively reduced level of salinity, the water contains sand which makes deep well water undrinkable in coastal areas (Ahmed 1996).

To cope with this disastrous situation, different water treatment options and alternative strategies like rainwater harvesting (RWH) and pond sand filter (PSF) systems are tried to adopt in government and non-government sectors. A part of these, United Nations Children's Emergency Fund (UNICEF) and Department of Public Health 
Engineering (DPHE) have been establishing PSF to purify pond water in saline affected coastal areas since 1983 (DPHE and UNICEF 1989). The PSFs which are made with brick, cement, sand, brick chips, net, hand tubewell, pvc pipe, filter media, etc. are established on the edge of pond to supply drinking water, in particular, in the salinity or arsenic-affected areas. Yokota et al. (2001) stated that PSFs can reduce both coliform and general bacteria, but it may not remove $100 \%$ of pathogen from heavily contaminated surface water. Rahman et al. (2001) mentioned that the PSF system, being a low cost technology, with very high efficiency in turbidity, colour and bacterial removal, may be considered as an alternative water supply system for small rural communities.

The Southwest coastal region of Bangladesh has been severely facing pure drinking water crisis due to saline water intrusion on one hand and arsenic content of groundwater on the other where PSFs have been installed as an alternative water supply system. Hence, this paper first investigates the present water demand (cooking and drinking) and supply scenario in the study area and socioeconomic aspects of PSFs. In addition, it evaluates the performance of PSFs in supplying safe drinking water through water quality analysis.

\section{Materials and methods}

Chalna Union of Dacope upazila in Southwest coastal region of Bangladesh has been selected as study area since the problem of safe drinking water is likely to be severely acute, and many PSF have already been established here as a supplementary drinking water source. Total number of households and population of Chalna union are 6,018 and 31,811, respectively (BBS 2001). A reconnaissance survey has been conducted prior to the selection of PSFs for study that helped to identify the active PSFs, and developed idea to prepare questionnaire. Water demand, existing water supply scenario and socio-economic aspects of PSF have been evaluated through questionnaire survey to the $10 \%$ (602) of the total households. Grab sampling was followed for laboratory experiments, and Stratified Random Sampling (based on the household's income) has been adopted for field survey. Equal number of households has been surveyed for each income group. Water samples were collected from 12 active PSFs (1. Chalna Paurashava Lake, 2. Perchalna, 3. Baruikhali, 4. Dacope Upazila, 5. Dacope hospital, 6. Khatail, 7. Lakshmikhola, 8. Khona, 9. Deluti, 10. Asavhua, 11. Gaurkhati and 12. Khalisha) and the relevant ponds during June to August 2007 (rainy season) considering all precautions. The water quality data have been obtained by laboratory analysis of collected samples and spot tests (laboratory of Khulna University, BUET, and the microbiological laboratory of DPHE, Khulna). 3 replications have been adopted for every location and the average values are finally plotted. $\mathrm{pH}$, salinity, EC and TDS were measured in the field using a portable $\mathrm{pH}$ meter (Hanna, pH 211), microprocessor salinity meter and EC/TDS meter (Hanna, H1-9635). Odour has been felt physically. Platinum-Cobalt Scale (ASTM D1209) method was used to measure colour. DO was measured using Winkler's method. Chloride $\left(\mathrm{Cl}^{-}\right)$was measured using Ion selective electrode method (Cole-palmer chloride electrode, model no. 27502-13). Total hardness, magnesium $\left(\mathrm{Mg}^{2+}\right)$ and calcium $\left(\mathrm{Ca}^{2+}\right)$ concentration has been examined by standard titrimetric method. Potassium $\left(\mathrm{K}^{+}\right)$was measured by flame photometric method (Flame photometer- models PEP 7 and PEP 7/C). Nitrate $\left(\mathrm{NO}_{3}{ }^{-}\right)$and sulphate $\left(\mathrm{SO}_{4}{ }^{2-}\right)$ concentration was measured by turbidimetric method using UV-visible spectrophotometers (Helios 9499230 45811). Phosphate $\left(\mathrm{PO}_{4}{ }^{3-}\right)$ concentration was accounted using ascorbic acid method (UV-visible spectrophotometers, Helios 9499230 45811). Arsenic concentration was measured using MERCK Arsenic Kit (no. 1.17926.0001). Membrane filtration technique was applied to study F. coliform.

\section{Results and discussion}

Water supply scenario and water demand

Chalna Union is a severely salinity intruded area in the Southwest coastal region of Bangladesh. PSF and tubewell are the major water supplier of the study area which is supplying about $70 \%$ of the total drinking water (Fig. 1). RWH system, newly introduced sustainable water supplier is not getting popularity and only used by the rich people due to high establishment costs. Some poor people are using pond water just after boiling even for drinking purposes. In addition, they are also using water from river, dug well and tap though the combined percentage of these water users are very small $(8.7 \%)$. The use of tubewell water is decreasing rapidly as it contains arsenic, salt and sand in most cases. Demand of fresh water for cooking and drinking purposes highly depends on income of the households. Drinking water demand is inversely related with the income whereas, cooking water is directly related. The low income groups mainly labours hard work and need more drinking water than the other income groups. In contrary, the rich people need more water for cooking than the poor as they cook varieties of food items every day. The average drinking and cooking water demand per head in the study area is about $5 \mathrm{~L} \mathrm{day}^{-1}$ (Table 1). 


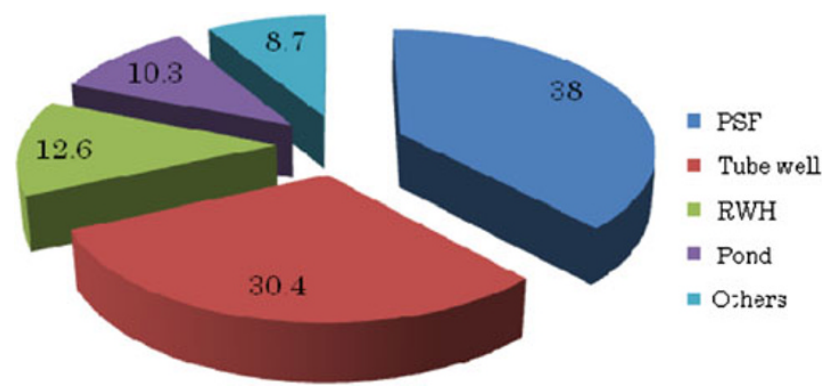

Fig. 1 Existing water (drinking and cooking) supply sources (\%) in the study area

Table 1 Water demand for drinking and cooking purposes

\begin{tabular}{|c|c|c|c|}
\hline $\begin{array}{l}\text { Income } \\
\text { groups } \\
\text { US\$ } \\
\text { (Households) }\end{array}$ & $\begin{array}{l}\text { Drinking } \\
(\text { Liter } \\
\text { Person }^{-1} \text { Day }^{-1} \text { ) }\end{array}$ & $\begin{array}{l}\text { Cooking } \\
(\text { Liter } \\
\text { Person }^{-1} \text { Day }^{-1} \text { ) }\end{array}$ & $\begin{array}{l}\text { Drinking }+ \text { cooking } \\
(\text { Liter } \\
\left.\text { Person }^{-1} \text { Day }^{-1}\right)\end{array}$ \\
\hline$<37$ & 3 & 2 & 5.1 \\
\hline $37-<60$ & 2.5 & 2.5 & \\
\hline $60-85$ & 2 & 3 & \\
\hline$>85$ & 2 & 3.5 & \\
\hline
\end{tabular}

Water quality of PSF

\section{Physical parameters}

The odour of all PSF's water seems to be satisfactory, though water of few ponds was slightly odorous. PSF shows high performance in removing colour (53-69\%) from pond water (Table 2) to acceptable limit (DoE 1997), while it reduces the TDS by $15 \%$ (average) enough to meet the DoE standard for more than $80 \%$ PSFs. Though PSF can reduce $\mathrm{pH}$ negligibly (0-3\%), $\mathrm{pH}$ of all PSF met DoE standard.

\section{Chemical parameters}

No detectable arsenic was found in the pond water. DO level of the studied PSF's water fall within Bangladesh standard. PSFs reduced salinity by $22 \%$ (average) of the corresponding pond's water, but still the salinity level is more than the DoE standard in all cases (Fig. 2). However, the users told that the salinity level is within their tolerable limit, and claimed for no health effect. The results

Table 2 Water quality parameters of PSFs and concerned ponds

\begin{tabular}{|c|c|c|c|c|c|c|c|c|c|c|c|c|c|c|c|}
\hline \multirow[t]{2}{*}{ Location } & \multirow[t]{2}{*}{ Sources } & \multicolumn{14}{|c|}{ Parameters } \\
\hline & & $\begin{array}{l}\text { Colour } \\
\text { (hazen) }\end{array}$ & $\begin{array}{l}\text { TDS } \\
(\mathrm{ppm})\end{array}$ & $\mathrm{pH}$ & $\begin{array}{l}\text { Salinity } \\
\text { (ppt) }\end{array}$ & $\begin{array}{l}\mathrm{Cl}^{-} \\
(\mathrm{ppm})\end{array}$ & $\begin{array}{l}\text { DO } \\
(\mathrm{ppm})\end{array}$ & $\begin{array}{l}\text { Hardness } \\
(\mathrm{ppm})\end{array}$ & $\begin{array}{l}\mathrm{K}^{+} \\
(\mathrm{ppm})\end{array}$ & $\begin{array}{l}\mathrm{Ca}^{2+} \\
(\mathrm{ppm})\end{array}$ & $\begin{array}{l}\mathrm{Mg}^{2+} \\
(\mathrm{ppm})\end{array}$ & $\begin{array}{l}\mathrm{NO}_{3}^{-} \\
(\mathrm{ppm})\end{array}$ & $\begin{array}{l}\mathrm{SO}_{4}{ }^{2-} \\
(\mathrm{ppm})\end{array}$ & $\begin{array}{l}\mathrm{PO}_{4}{ }^{3-} \\
(\mathrm{ppm})\end{array}$ & $\begin{array}{l}\text { F. coliform } \\
\text { (no./ml) }\end{array}$ \\
\hline \multirow[t]{2}{*}{1} & Pond & 32 & 970 & 6.8 & 3 & 540.5 & - & 240.8 & 15.5 & 59 & 22.4 & 1.2 & 16.7 & 0.29 & 49 \\
\hline & PSF & 11.2 & 840 & 6.7 & 2 & 538.6 & 6.5 & 215 & 13.4 & 56.2 & 20.2 & 0.82 & 10.6 & 0.18 & 0 \\
\hline \multirow[t]{2}{*}{2} & Pond & 34 & 984 & 6.9 & 2.6 & 545 & - & 237.5 & 14.5 & 57.4 & 22.8 & 1.01 & 49.2 & 0.32 & 247 \\
\hline & PSF & 10.5 & 837 & 6.8 & 1.91 & 541.2 & 6.8 & 212.3 & 13.6 & 54.8 & 21.1 & 0.72 & 30.5 & 0.23 & 3 \\
\hline \multirow[t]{2}{*}{3} & Pond & 34.5 & 992 & 7.1 & 2.5 & 601 & - & 224 & 13.3 & 57 & 18 & 1.1 & 25 & 0.8 & 536 \\
\hline & PSF & 12 & 821 & 7.1 & 1.6 & 601 & 6.4 & 192.5 & 11.5 & 54.8 & 13.5 & 0.77 & 17.3 & 0.44 & 8 \\
\hline \multirow[t]{2}{*}{4} & Pond & 19.3 & 512 & 7.2 & 1.9 & 159 & - & 132 & 8.5 & 34.5 & 13 & 1.15 & 18.5 & 0.15 & 30 \\
\hline & PSF & 6.6 & 407 & 7 & 1.3 & 143.2 & 7.5 & 105.3 & 6.85 & 29.3 & 11.5 & 0.9 & 11 & 0.1 & 0 \\
\hline \multirow[t]{2}{*}{5} & Pond & 38.6 & 1560 & 7.3 & 3.25 & 978 & - & 287 & 12.5 & 60 & 36 & 1.28 & 65.4 & 1.1 & 793 \\
\hline & PSF & 14.5 & 1415 & 7.2 & 1.96 & 969.8 & 7 & 258.7 & 11.7 & 52.3 & 32.1 & 1.13 & 40.1 & 0.5 & 15 \\
\hline \multirow[t]{2}{*}{6} & Pond & 36.8 & 1423 & 7.2 & 4 & 802.4 & - & 265.2 & 17.8 & 56 & 32 & 1.3 & 45.6 & 1.12 & 623 \\
\hline & PSF & 13.7 & 1285 & 7.1 & 2.3 & 800 & 7.2 & 246 & 16.7 & 52 & 29.5 & 1.05 & 31.8 & 0.58 & 8 \\
\hline \multirow[t]{2}{*}{7} & Pond & 28.4 & 858 & 6.8 & 2.3 & 526.4 & - & 218 & 12.6 & 51.7 & 20.5 & 1 & 24 & 0.2 & 376 \\
\hline & PSF & 9.8 & 735 & 6.7 & 1.85 & 526.4 & 7.5 & 191 & 11 & 46.5 & 17.6 & 0.8 & 16.2 & 0.12 & 2 \\
\hline \multirow[t]{2}{*}{8} & Pond & 30.3 & 980 & 7 & 2.5 & 537 & - & 225.6 & 13.5 & 55.6 & 25 & 1.08 & 28.6 & 0.32 & 197 \\
\hline & PSF & 13.6 & 823 & 6.9 & 2 & 529.5 & 6.7 & 190 & 11.4 & 53.3 & 23 & 0.8 & 22.3 & 0.21 & 1 \\
\hline \multirow[t]{2}{*}{9} & Pond & 36 & 1035 & 7 & 3 & 658 & - & 247 & 12.8 & 59 & 28.2 & 1.18 & 47.3 & 0.7 & 324 \\
\hline & PSF & 14 & 906 & 6.8 & 2 & 653.4 & 7 & 225.8 & 12 & 56.4 & 25.8 & 1.01 & 30 & 0.43 & 5 \\
\hline \multirow[t]{2}{*}{10} & Pond & 35.2 & 988 & 7 & 2.9 & 560 & - & 238.4 & 13.4 & 55.8 & 23 & 1.12 & 19 & 0.45 & 452 \\
\hline & PSF & 15 & 825 & 7 & 2.1 & 560 & 6.4 & 218.2 & 12.1 & 52.5 & 20.4 & 0.87 & 12.2 & 0.24 & 6 \\
\hline \multirow[t]{2}{*}{11} & Pond & 28 & 897 & 7.1 & 2.2 & 525 & - & 220 & 10.8 & 50 & 19.7 & 1.06 & 27.6 & 0.28 & 175 \\
\hline & PSF & 13.1 & 736 & 7 & 1.76 & 523.4 & 6.5 & 195.3 & 8.9 & 44.2 & 14.8 & 0.93 & 18.5 & 0.15 & 2 \\
\hline \multirow[t]{2}{*}{12} & Pond & 22.4 & 753 & 6.8 & 2 & 325 & - & 186.2 & 9.2 & 45.3 & 16 & 1.04 & 15 & 0.14 & 50 \\
\hline & PSF & 8.5 & 608 & 6.7 & 1.57 & 312.2 & 7 & 150.8 & 7.8 & 39.1 & 12.8 & 0.77 & 9.1 & 0.11 & 0 \\
\hline
\end{tabular}




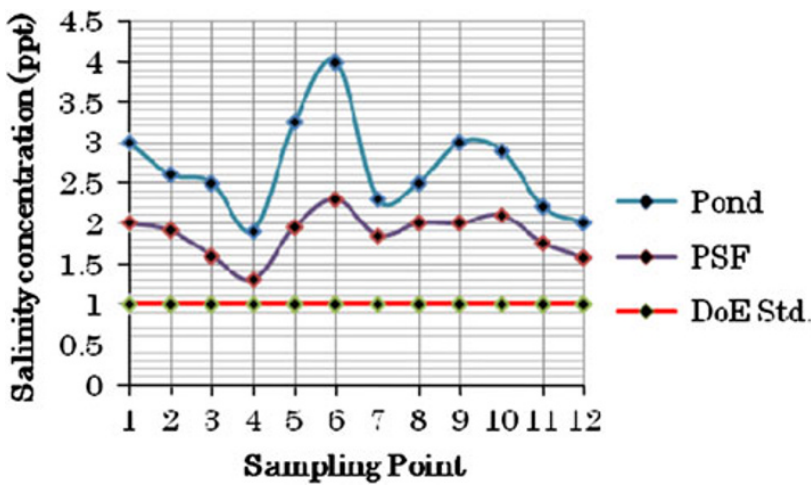

Fig. 2 Efficiency of PSF to reduce salinity in meeting DoE standard

expressed that PSF is able to remove hardness, potassium, calcium, magnesium, nitrate, sulphate and phosphate by $1.5,12.3,11.9,8.2,13.3,22,34.5$ and $39.6 \%$ (average), respectively (Table 2), and meet DoE standard except for potassium which exceeds the standard for one-third PSFs. PSF is unable to remove chloride, however, the negligible reduction of chloride $(1.5 \%)$ in our study might be due to the oxidation that is supported by literature (Dunlop et al. 2002).

\section{Biological parameters}

Though PSF is efficient in removing Coliform bacteria (98-100 \%) however still few pathogens may exist in the PSF's water (Fig. 3) specially, while the pond is highly polluted. As most of the PSFs in our study did not meet DoE standard $(0 / 100 \mathrm{ml}$ water) in terms of bacterial contamination, many users have been suffering from stomach diseases drinking contaminated water.

\section{Comparison of PSF water with WHO standard}

The analytical parameters of the PSF water were also compared with the recommended value of World Health

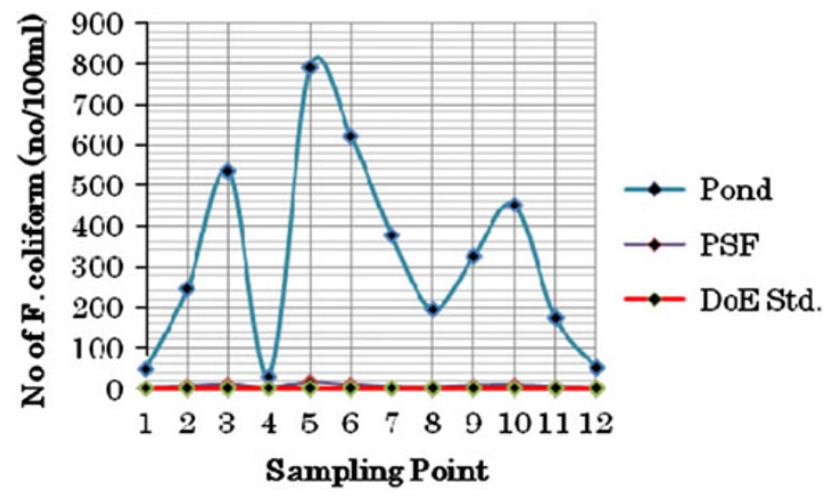

Fig. 3 Performance of PSF in removing $F$. coliform
Organization (WHO 1993). It was found that only chloride, potassium and F. coliform with values of 25,33 and $75 \%$ PSF water exceed the allowable limits of WHO, respectively (Table 3 ).

Socio-economic aspects of water supply

\section{Satisfaction level of PSF users}

Only $20 \%$ of the PSF users are fully satisfied using PSF's water which is so small in comparing partially satisfied $(50 \%)$ and dissatisfied (30\%) groups (Fig. 4a). The main reason for the dissatisfaction is waiting for long time in a queue to take water specially, to the women (mainly responsible to bring water) who also have to take care of the children, cooking, washing, etc. (Fig. 4b). About onethird of the users have observation of the scarcity of PSF as they have to walk a long distance (average $2 \mathrm{~km}$ ) to bring water. Some users $(10 \%)$ also claimed about the water quality of the PSF, who think that due to lack of maintenance of PSF water quality is becoming poor and results in diarrhea, dysentery and other diseases of stomach, while a part $(10 \%)$ of the respondents have dissatisfaction for not to manage the pond properly (free from bathing, washing, aquaculture, agricultural outlets, etc.). The villagers think that the PSF could be a sustainable alternative drinking water source in the coastal region if it is installed within the tolerable distance of the users. They also have an idea of

Table 3 Comparison of PSFs water with WHO drinking water standard

\begin{tabular}{|c|c|c|c|c|}
\hline \multirow{2}{*}{$\begin{array}{l}\text { Water } \\
\text { quality } \\
\text { parameters }\end{array}$} & \multicolumn{2}{|c|}{ WHO (1993) } & \multirow{2}{*}{$\begin{array}{l}\text { Samples } \\
\text { exceeding } \\
\text { allowable } \\
\text { limits }\end{array}$} & \multirow{2}{*}{$\begin{array}{l}\text { Percentage of } \\
\text { samples } \\
\text { exceeding } \\
\text { allowable limits }\end{array}$} \\
\hline & $\begin{array}{l}\text { Desirable } \\
\text { limit }\end{array}$ & $\begin{array}{l}\text { Maximum } \\
\text { allowable } \\
\text { limit }\end{array}$ & & \\
\hline $\begin{array}{l}\text { Colour } \\
\text { (hazen) }\end{array}$ & - & 15 & Nil & Nil \\
\hline $\begin{array}{l}\text { TDS } \\
\text { (ppm) }\end{array}$ & 500 & 1,500 & Nil & Nil \\
\hline $\mathrm{pH}$ & $7.0-8.5$ & 9.2 & Nil & Nil \\
\hline $\mathrm{Cl}^{-}(\mathrm{ppm})$ & 200 & 600 & $5,6,9$ & 25 \\
\hline $\mathrm{K}^{+}(\mathrm{ppm})$ & - & 12 & $1,2,6,10$ & 33 \\
\hline $\begin{array}{l}\mathrm{Ca}^{2+} \\
\quad(\mathrm{ppm})\end{array}$ & 75 & 200 & Nil & Nil \\
\hline $\begin{array}{l}\mathrm{Mg}^{2+} \\
\quad(\mathrm{ppm})\end{array}$ & 50 & 150 & Nil & Nil \\
\hline $\begin{array}{l}\mathrm{NO}_{3}^{-} \\
(\mathrm{ppm})\end{array}$ & 45 & - & Nil & Nil \\
\hline $\begin{array}{l}\mathrm{SO}_{4}^{2-} \\
\quad(\mathrm{ppm})\end{array}$ & 200 & 400 & Nil & Nil \\
\hline As (total) & 0.01 & 0.01 & Nil & Nil \\
\hline $\begin{array}{c}\text { F. coliform } \\
\text { (no./ml) }\end{array}$ & $0 / \mathrm{ml}$ & $0 / \mathrm{ml}$ & $2,3,5-11$ & 75 \\
\hline
\end{tabular}




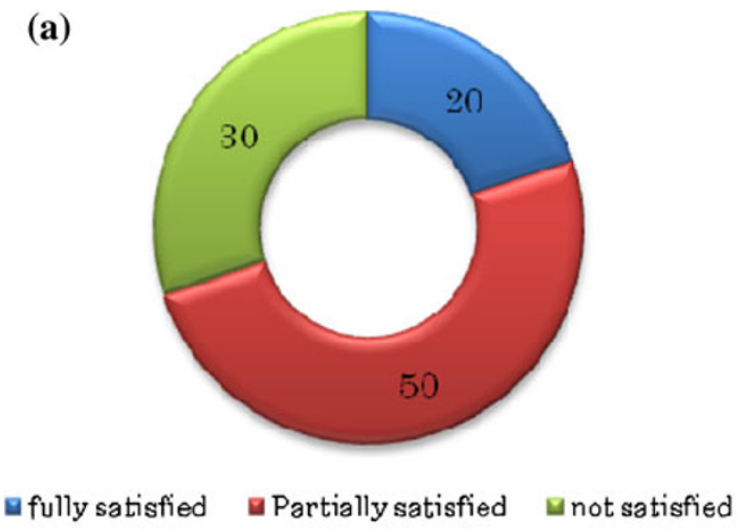

(b)

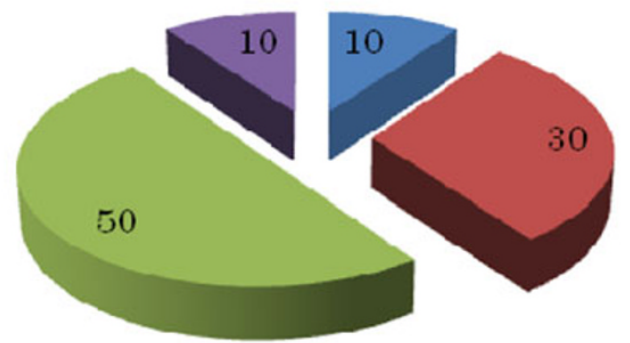

\section{water quality}

walking long distance

waiting to take water

a pond migmanagement

Fig. 4 a Satisfaction level (\%) of the existing PSF water users, b reasons for dissatisfaction

proper pond selection, management of pond and maintenance of PSF periodically, test of water quality in a continuous basis, supplying bacteria free water, etc. to enhance the familiarity of PSF.

\section{Economic feasibility}

As the majority of coastal people are poor the viability of water supply technology predominantly depends on their willingness to pay. Table 4 shows the installment and maintenance cost of the suitable water supply technologies along with the number of households that could be covered by it. Though the coastal people badly need safe drinking water, their low income level limits the desire to pay for water (Table 5) while they have lack of foods. It seems from table 4 and 5 that about $39 \%$ of the total households with monthly income level US\$ 60 or more have the ability to afford RWH system both in terms of installment and maintenance cost in contrast with the majority of the poor households (about $61 \%$ ) who can only afford the PSF. In contrary, no household is able to afford ultrafiltration technology due to high installment cost.

\section{Conclusions}

The people in the study area have been still suffering drinking water problems both quantitatively and

Table 4 Cost of PSF, RWH and Ultrafiltration technology

\begin{tabular}{llll}
\hline Technology & $\begin{array}{l}\text { Installment } \\
\text { cost (US\$) }\end{array}$ & $\begin{array}{l}\text { Maintenance cost } \\
\text { (US\$ Year }^{-1} \text { ) }\end{array}$ & $\begin{array}{l}\text { No. of family } \\
\text { can use }\end{array}$ \\
\hline PSF & $493-740$ & 49 & $60-100$ \\
RWH & $49-62$ & 12 & $\begin{array}{l}\text { Individual } \\
1000^{*}\end{array}$ \\
Ultrafiltration & 24000 & Unknown & \\
\hline
\end{tabular}

Source, DPHE 2009

* Calculated as of Arnal et al. (2009)
Table 5 Relation between income level and willingness to pay for drinking water technology

\begin{tabular}{llll}
\hline $\begin{array}{l}\text { Households income } \\
\text { level (US\$ Month }\end{array}$ & $\begin{array}{l}\text { Percentage of } \\
\text { total households }\end{array}$ & $\begin{array}{l}\text { Willingness to pay for } \\
\text { drinking and cooking water } \\
\text { (US\$) }\end{array}$ \\
\cline { 2 - 4 } & & $\begin{array}{l}\text { Installment of } \\
\text { technology } \\
\text { (once) }\end{array}$ & $\begin{array}{l}\text { For } \\
\text { water } \\
\text { (daily) }\end{array}$ \\
\hline$<37$ & 35.45 & 6 & 0.025 \\
$37-<60$ & 25.91 & 12 & 0.038 \\
$60-85$ & 13.93 & 49 & 0.063 \\
$>85$ & 24.71 & 62 & 0.088 \\
\hline
\end{tabular}

Source, Field survey 2007 and BBS 2001

qualitatively. PSF is supplying the major percentage of drinking water in spite of having the limitation of water quality and scarcity. Both drinking and cooking water demand depends on income groups, for instance, low income people need more drinking water in contrast to the high income people who need more cooking water. The water quality of PSF highly depends on the water quality of the corresponding ponds. PSF is not appropriate for the ponds that contain high salinity, Potassium and Chloride. As most of the PSFs are unable to remove the coliform completely, disinfection must be adopted after filtration to ensure pure drinking water supply. Ultrafiltration technology, having the capacity to remove total coliform by $100 \%$ is not effective to the coastal region of Bangladesh due to high capital cost (Arnal et al. 2009). Periodic water quality monitoring and maintenance of PSF along with the proper selection and management of pond could ensure the safe drinking water to the coastal Bangladesh. About $40 \%$ of the inhabitants who have ability to afford RWH system could be occupied by it to avoid the load on PSF, and the installment of additional PSFs to a certain distance would minimise the walking and waiting for long distance and time, respectively, to bring water. Further study on using 
activated carbon in removal of excess salinity (Zou et al. 2008) and coliform (Matsunaga et al. 1994) of PSF water might make sense of using PSF with slight modification.

Acknowledgments The authors would like to acknowledge the respondents who had given their time and merits during questionnaire survey. Special thanks to the authorities who helped providing information and laboratory supports to accomplish the research.

Open Access This article is distributed under the terms of the Creative Commons Attribution License which permits any use, distribution, and reproduction in any medium, provided the original author(s) and the source are credited.

\section{References}

Ahmed MF (1996) Coastal Water Supply in Bangladesh, Reaching the Unreached: Challenges for the 21st Century. Proceedings of 22nd WEDC Conference, New Delhi, India

Ahmed MF, Rahman MM (2000) Water Supply and Sanitation: Rural and Low Income Urban Communities, 1st edn. ITN Bangladesh, Dhaka

Arnal JM, Garcia-Fayos B, Verdu G, Lora J (2009) Ultrafiltration as an alternative membrane technology to obtain safe drinking water from surface water: 10 years of experience on the scope of the AQUAPOT project. Desalination 248:34-41

BBS (2001) Statistical year book of Bangladesh. Bangladesh Bureau of Statistics, Dhaka

DoE (1997) Drinking water quality standard guideline. Department of Environment, Bangladesh

DPHE (2009) Annual report. Department of Public Health Engineering, Khulna
DPHE and UNICEF (1989) A report on the development of pond sand filtration. Department of Public Health Engineering, Dhaka

Dunlop PSM, Byrne JA, Manga N, Eggins BR (2002) The photocatalytic removal of bacterial pollutants from drinking water. J Photochem Photobiol, A 148:355-363

Karim MM, Safiuddin M (2003) Water resources management in the remediation of groundwater arsenic contamination in Bangladesh. Backhuys, Leiden

Matsunaga T, Nakasono S, Kitajima Y, Horiguchi K (1994) Electrochemical disinfection of bacteria in drinking water using activated carbon fibers. Biotechnol Bioeng 43(5):429-433

Rahman MH, Mamtaz R, Ferdausi SA (1997) Pilot solar desalination plants in Bangladesh. Proceedings of 23rd WEDC Conference on Water and Sanitation for All: Partnerships and Innovations, Durban, South Africa

Rahman A, Ali MA, Chowdhury F (2001) People's Report on Bangladesh Environment 2001, vol. I. The University Press Limited, Dhaka, pp 111-119

UNDP (1992) The human development report. United Nations Development Program, New York

WHO (2004) Occurrence of cyanobacterial toxins (microcystins) in surface waters of rural Bangladesh., Water, Sanitation and Health Protection of the Human EnvironmentWorld Health Organization, Geneva

WHO (1993) Guidelines for drinking water quality, vol. 1, 2nd edn. World Health Organization, Geneva

Yokata HK, Tanabe M, Sezaki T, Akiyoshi T, Miyata K, Kawahara S, Tsushima H, Hironaka H, Takafuji M, Rahman SA, Ahmed MHSU, Faruquee MH (2001) Arsenic contamination of ground and pond water and water purification system using pond water in Bangladesh. Eng Geol 60:323-331

Zou L, Morris G, Qi D (2008) Using activated carbon electrode in electrosorptive deionisation of brackish water. Desalination 225(1-3):329-340 